\title{
Productivity or Production: Appraising Growth Solution for Indian SMEs
}

\author{
Sangeeta Sharma ${ }^{1 *}$, Kunal Vashisth ${ }^{2}$ and Tavishi Sharma ${ }^{3}$ \\ ${ }^{1}$ Department of Commerce, D.A.V.Centanary College, Faridabad, India \\ ${ }^{2}$ Business Intelligence Consultant, Cloudsteer Technologies Pty Ltd, Gurgaon, India \\ ${ }^{3} 4 / 4$ Yr. Computer Science and Engineering, Lingayas University, Faridabad, India
}

\begin{abstract}
In an era of continuing rising prices of commodities, fluctuating energy costs, high taxes, government regulations, capital shortage, worker dissatisfaction, intense foreign competition and inadequate productivity, throws a big challenge in managing manufacturing unit in SME sector. The performance of Indian SMEs is deteriorating rapidly and continually. For making these firms on track, certain patented methods and techniques need to be implemented for reducing the cost of manufacture. As the global companies are putting best drives to cut down the manufacturing cost by using all practices at par with productivity concept, it has been seen that Indian SMEs are still a victim of production or quantity game. Such a production-oriented philosophy is eroding its growth. In this context, we have put efforts to understand the concept of productivity as understood by SMEs and the status of its implementation in manufacturing system which has been found alarming. Based on the research findings, we have suggested certain drivers which need to be run immediately for the sustainability and growth. The paper further discusses the implications of study and highlights the new streams for future researchers in this area.
\end{abstract}

Keywords: Commodities; Capital; SMEs; Techniques; Productivity; Sustainability

\section{Introduction}

Production is a conversion function by which goods and services are produced over a period of time while productivity is the ability of an organization or company to convert available resources into profitable services or goods. Productivity in the work place makes use of skills, technology and innovative ideas to achieve maximum output with the inputs and processes. Thus, productivity is all about exploring new ways to build an efficient environment creating wealth to an organization. Mathematically, Productivity $=$ (Output volumes) / (Input). Increased production due to efficient utilization of organizational resources leads to a lower cost production resulting in better sales and improved bottom-line of a business entity. Significant productivity increases in long run cannot be achieved solely by increased worker effort. Real growth can happen only through capital investment in newer and better machines equipment and facilities. In addition, attention to improved worker motivation and incentives such as profit sharing increases productivity.

Production processes can be represented by production or transformation functions at various levels of the economy. Production functions relate maximum producible output to sets of available inputs.

- Producers behave efficiently, i.e. they minimize costs and/or maximize revenues.

- Markets are competitive, and market participants are pricetakers who can only adjust quantities but not individually act on market prices.

The importance of productivity can never be ignored by any diligent business owner. Successful ventures are often those that give priority to productivity compared to solely looking into revenues and profits of the company. On the other hand, businesses that do not pay attention to productivity pay a huge price in terms of reduced production and high cost of production, resulting in reduced sales and low profits.

In this era of towering competitiveness, Indian SMEs are failing miserably on cost of its products. Higher costs are making those uncompetitive and eroding the future growth. As the cost of inputs are market driven and cost of output are customer driven, only one way left is to produce cost-effectively. SMEs are busy in supplying the scheduled quantities to retain the customer and in this process companies becomes production oriented rather than becoming productive. Optimal usage of all resources related to man, material, machine, method and money is must to stand erect in global market field.

In context of this study, in specific for SMEs in auto component manufacturing units in Indian automobile industry, we are putting an effort on evaluating the following:

1. Whether the SMEs really understand the difference in "Production Quantity" and "Productivity"

2. How these units are competing while being Production-Oriented and Productivity-Oriented.

3. And exploring the ways and means to improve upon "Productivity" front.

\section{Review of Literature}

Productivity has been studied by almost all governments and giant OEMs. There is many research assignments throwing light on the benefits of productivity. Describing role of human capital and technology [1], narrated that according to the human capital theory, human capital contributes to output just like other factors of production and also through technological change by driving both innovation and imitation.

*Corresponding author: Sangeeta Sharma, Department of Commerce D.A.V. Centanary College, Faridabad, India, Tel: 0129-2415044; E-mail: dr.sangeetasharma44@gmail.com

Received August 25, 2014; Accepted September 11, 2014; Published September 21,2014

Citation: Sharma S, Vashisth K, Sharma T (2014) Productivity or Production: Appraising Growth Solution for Indian SMEs. Int J Econ Manag Sci 3: 185. doi: 10.4172/2162-6359.1000185

Copyright: ( 2014 Sharma S, et al. This is an open-access article distributed under the terms of the Creative Commons Attribution License, which permits unrestricted use, distribution, and reproduction in any medium, provided the original author and source are credited. 
Describing the importance of R\&D in enhancing the productivity, (see, e.g., the endogenous growth models in [2]), that R\&D, in turn, is a key factor for technological progress and productivity growth. Furthermore, Aggrey et al. [1] in their study have shown that the effect of education and training on labour productivity was positive and significant in bringing about cost effective change. Despite these indexes, in most of studies $\mathrm{R} \& \mathrm{D}$ expenditures is used as a proxy of knowledge capital of firms. By improvement in technology, the level of per worker output will increase, so any factor like R\&D expenditures that causes technology improvement will increase labour productivity [3]. Technological change drives long-term economic growth and improved standards of living. This is a well-documented observation $[4,5]$. The Indian economy registered a TFP growth rate of 1.4 per cent during 1980-2008. There has been an improvement in productivity growth during 2000-2008 (2.3 per cent) over the period 1980-1999 (1.1 per cent).

This seems to be also true in the long term. In fact, technology developed elsewhere could be very expensive because, in order to acquire relatively advanced knowledge, the borrower must develop an innovative capacity. Commenting on comparison of US productivity with India, Hsieh and Klenow [6] ask how much larger the Chinese and Indian economies would be if they achieved the same efficiency in allocating inputs across production units as does the United States. In industrial organization, various researches have connected the productivity with features of technology, demand, and market structure. Examples include the effect of competition [7]. While studying the productivity of assembly line by using lean concepts, Van Biesebroeck $[8,9]$ measures the productivity impact of auto assembly plants shifting to "lean" technologies, which in that context involves investment of new capital plus a host of complementary practices. A survey was conducted by Bloom [10] and much of what was scored as "best practice" management in the interviews was based on the recommendations of the management consulting industry. This pointed out questions about whether these practices represents performance, or just relates to the management wish list.

While studying the impact of training, Restak [11] concluded that everyone has the same sorts of muscles and they respond to training in the same sorts of ways: daily training is far more effective in building strength and endurance than occasional lengthy sessions. Similarly, people's brains are similar in structure and, at all ages, respond to training

Research conducted by Dearden et al. [12] in the production sector of the UK found that raising the proportion of employees trained in an industry from $10 \%$ to $15 \%$ is associated with at least a 3 percentage point increase in the value added per worker. Study of Caselli [13] shows that, in a quantitative sense, human capital cannot be viewed as a very significant factor to explain the adoption of different technologies.

Thus, above studies reveals that productivity of all required inputs contributes to profit maximization by using those optimally. Also, during the survey on related research, we have not come across a single study throwing light on the research topic under this study. This has motivated us to select this topic for enhancing the wealth maximization of Indian SMEs in densely populated sector that is automobile industry.

\section{Objective of Study}

Any study for the benefit of industries will definitely add fuel to its growth, profitability and profit maximization. In this case, we have selected SMEs in Indian automobile as such units have maximum population; thus, will give maximum impact on National GDP. The main objective of this study is to understand the adoption, implementation and inferences of concept of production and productivity with regard to Indian SMEs and suggest the best remedial solutions for profit maximization.

\section{Research Design}

This research is purely an empirical in nature based on primary data collection from SMEs in Indian automobile industry. Fifty companies were selected for study; four of the entrepreneurs did not responded at all. The sample size of the companies is limited to the geography of NCR-Delhi in India. Table 1 represents the sample size of SMEs manufacturing different products which are a part of automobile.

Furthermore, for analyses, interpretation and conclusion of the study, following hypotheses have been generated for testing the validity.

H01: Production is still a buzz word in Indian SMEs.

H02: Indian SMEs are failing measurably in gauging the productivity of resources.

H03: Despite of being productive, Indian SMEs are always busy in quantity game.

H04: Neither management nor workforce opt requisite drives for becoming productive.

H05: Productivity suffers due to deployment of contractual work culture in key areas.

H06: Implementation of QMS rather than its accrediting helps becoming productive.

\section{Analysis and Intrepretation}

Designed questionnaire were sent to the respondents as well as personal contact program by interviewing the respondents was adopted. Personal contact program was found more effective in this case. Data were collected and arranged in tabular form. All "yes" answers or affirmative answers were tabulate. Responses with regard to productivity have been put in Table 2, below.

Note: Above table highlights that twenty six percent managers, twenty percent supervisor and three percent workers concept are familiar to the culture of being productive. Overall, sixteen percent of employees believe in productivity while eighty four percent are busy in quantity game. Thus, null hypotheses $\mathrm{H} 01$ and $\mathrm{H} 03$ are true and productivity is only buzz word for Indian SMEs and those are busy in fulfilling the monthly quantity of goods supplied rather than producing linear quantity on periodic basis.

The favorable responses on implementing QMS have been arrayed in Table 3. Three broader categories i.e. managers, supervisors and

\begin{tabular}{|c|l|c|c|}
\hline S.No. & \multicolumn{1}{|c|}{ CATAGORY OF MANUFACTURER } & SIZE & PERCENT \\
\hline 1 & Forging Companies & 4 & 9 \\
\hline 2 & Casted Auto Component companies & 10 & 22 \\
\hline 3 & Sheet Metal Auto Component Manufacturer & 6 & 13 \\
\hline 4 & Tool and Die makers & 5 & 11 \\
\hline 5 & Fabricator of Auto Component & 6 & 13 \\
\hline 6 & Sub Assembly producers & 3 & 6 \\
\hline 7 & Rubber component & 3 & 6 \\
\hline 8 & General Engineering units & 7 & 16 \\
\hline 9 & Metallic coating/Plating units & 2 & 4 \\
\hline & TOTAL & 46 & 100 \\
\hline
\end{tabular}

Table 1: Sample size of companies under study. 


\begin{tabular}{|c|l|c|c|c|}
\hline S.No & \multicolumn{1}{|c|}{$\begin{array}{c}\text { DESCRIPTION OF } \\
\text { PARAMETER }\end{array}$} & MANAGER & SUPERVISOR & OPERATOR \\
\hline 1 & $\begin{array}{l}\text { Production is accounted } \\
\text { for hourly basis }\end{array}$ & 8 & 6 & 0 \\
\hline 2 & $\begin{array}{l}\text { You maintain linearity in } \\
\text { production }\end{array}$ & 8 & 6 & 0 \\
\hline 3 & $\begin{array}{l}\text { Do you measure } \\
\text { productivity }\end{array}$ & 8 & 6 & 0 \\
\hline 4 & $\begin{array}{l}\text { Productivity is preferred } \\
\text { over Production }\end{array}$ & 18 & 16 & 14 \\
\hline 5 & $\begin{array}{l}\text { All operators produce } \\
\text { equal quantity/shift }\end{array}$ & 12 & 16 & 10 \\
\hline 6 & $\begin{array}{l}\text { Your delivery rating } \\
\text { exceeds 96\% }\end{array}$ & 18 & 8 & 10 \\
\hline 7 & $\begin{array}{l}\text { Rejects are in ppm not in } \\
\text { percentages }\end{array}$ & 12 & 6 & 0 \\
\hline 8 & $\begin{array}{l}\text { Does your hourly } \\
\text { production not vary }\end{array}$ & 8 & 6 & 0 \\
\hline 10 & $\begin{array}{l}\text { O.E.E and Yields are } \\
\text { regularly monitored }\end{array}$ & 8 & 16 & 14 \\
\hline 11 & $\begin{array}{l}\text { Your quality rating always } \\
\text { exceed 96\% }\end{array}$ & 18 & 20 & 3 \\
\hline & PERCENT & 26 & 16 & \\
\hline & Overall (Percent) & & 8 \\
\hline
\end{tabular}

Table 2: Affirmative response of various hierarchies on productivity.

operators have been question for drawing an overall view of employees.

Table 3 exhibits that most of the companies are accredited to QMS, yet, twenty three percent managers, eighteen percent supervisors and thirteen percent operators (overall eighteen percent) opined that its accreditation make the system productive. On the other hand eighty two percent of overall employees believe that implementing QMS can only bring about the productivity into the manufacturing system, which is in line with null hypothesis H05.

Respondents were tested for using the various methods to become productive. Affirmative responses have been garlanded in Table 4 below.

Table 4, reveals that twenty three percent managers, seventeen percent supervisors and thirteen percent operators (overall eighteen percent) has voted affirmative in using various techniques for productivity. A great ratio of overall eighty two percent employees sees productivity with strange eyes. Thus, null hypothesis that "Indian SMEs are not failing measurably in gauging the productivity of resources" and "Neither management nor workforce opt requisite drives for becoming productive is true in case of Indian SMEs.

The study further investigated the role of contractual workers on the context of productivity. The data collected have been arranged in Table 5 as mentioned below.

Above Table 5 explains that fifty five percent managers, fifty percent each supervisors and operators believe that contractual worker are an aid to meet the production targets while being working even in key area. Such worker do change still they undergo training by a trained operator or staff for accomplishing the specific job. Overall, fifty two percent of total employees favor contractual working along with permanent employees. Thus, null hypothesis "Productivity suffers due to deployment of contractual work culture in key areas" does not hold true and alternate hypothesis i.e. contractual workers add fuel to productivity and are not an obstacle to it at all.

Overall impact of various factors responsible for productivity has been put up in Table 6 below.
Table 6 elaborates that there is a wide gap of twenty three percent among employees in understanding and implementing productivity. The biggest worry is worker and operators hardly understand to be productive (three percent only). This gap is ten percent in case of management support and implementation of QMS. Range on the opinion about contractual works is very narrow (five percent).Overall, only twenty five percent employees has favored productivity culture with a wide range of fourteen percent among themselves.

\section{Results and Discussion}

Table 1 shows that there is a wide gap in understanding and implementing the concept of productivity between manager and supervisor by six percent which extends to worker by twenty three percent. Thus, employees of Indian SMEs in automobile industry

\begin{tabular}{|c|c|c|c|c|}
\hline S.No & $\begin{array}{l}\text { DESCRIPTION OF } \\
\text { PARAMETER }\end{array}$ & MANAGER & SUPERVISOR & OPERATOR \\
\hline 1 & $\begin{array}{l}\text { Company is accredited to } \\
\text { QMS }\end{array}$ & 38 & 32 & 32 \\
\hline 2 & $\begin{array}{l}\text { Rejection increases } \\
\text { Production target }\end{array}$ & 22 & 28 & 34 \\
\hline 3 & $\begin{array}{l}\text { Company send you for } \\
\text { outstation training }\end{array}$ & 16 & 8 & 0 \\
\hline 4 & $\begin{array}{l}\text { In plant Training is } \\
\text { regularly imparted }\end{array}$ & 22 & 18 & 12 \\
\hline 5 & $\begin{array}{l}\text { Company celebrates } \\
\text { improvement plans }\end{array}$ & 12 & 6 & 2 \\
\hline 6 & $\begin{array}{l}\text { Best worker awards are } \\
\text { regularly given }\end{array}$ & 18 & 16 & 12 \\
\hline 7 & $\begin{array}{l}\text { Rework is not a regular } \\
\text { practice in company }\end{array}$ & 18 & 9 & 6 \\
\hline 8 & $\begin{array}{l}\text { Company's layout is work } \\
\text { supportive }\end{array}$ & 22 & 16 & 6 \\
\hline 9 & $\begin{array}{l}\text { Customers often witness } \\
\text { process audit }\end{array}$ & 24 & 18 & 8 \\
\hline \multirow[t]{3}{*}{10} & $\begin{array}{l}\text { QMS implementation } \\
\text { increases output }\end{array}$ & 40 & 32 & 14 \\
\hline & Average(Percent) & 23 & 18 & 13 \\
\hline & Overall (Percent) & \multicolumn{3}{|c|}{18} \\
\hline
\end{tabular}

Table 3: Affirmative response on QMS practices.

\begin{tabular}{|c|c|c|c|c|}
\hline S.No & $\begin{array}{l}\text { DESCRIPTION OF } \\
\text { PARAMETER }\end{array}$ & MANAGER & SUPERVISOR & OPERATOR \\
\hline 1 & $\begin{array}{l}\text { Management drives for } \\
\text { being productive }\end{array}$ & 22 & 18 & 16 \\
\hline 2 & $\begin{array}{l}\text { Lean manufacturing is your } \\
\text { work culture }\end{array}$ & 8 & 4 & 0 \\
\hline 3 & $\begin{array}{l}\text { Company has JIT system } \\
\text { in place }\end{array}$ & 3 & 0 & 0 \\
\hline 4 & Are you trying for 6 -sigma & 2 & 0 & 0 \\
\hline 5 & $\begin{array}{l}\text { Are cross functional core } \\
\text { teams in place }\end{array}$ & 12 & 11 & 10 \\
\hline 6 & $\begin{array}{l}\text { Company practices TPM } \\
\text { Techniques }\end{array}$ & 12 & 11 & 10 \\
\hline 7 & $\begin{array}{l}\text { Predictive maintenance is } \\
\text { regular feature }\end{array}$ & 3 & 0 & 0 \\
\hline 8 & $\begin{array}{l}\text { Outputs are standardized/ } \\
\text { equipment }\end{array}$ & 18 & 12 & 10 \\
\hline 9 & $\begin{array}{l}\text { Inputs are received ahead of } \\
\text { production }\end{array}$ & 22 & 18 & 8 \\
\hline 10 & $\begin{array}{l}\text { Company has adequate } \\
\text { resources always }\end{array}$ & 8 & 4 & 4 \\
\hline & Average (Percent) & 23 & 17 & 13 \\
\hline & Overall (Percent) & \multicolumn{3}{|c|}{18} \\
\hline
\end{tabular}

Table 4: Affirmative responses on being productive. 


\begin{tabular}{|c|l|c|c|c|}
\hline S.No & \multicolumn{1}{|c|}{$\begin{array}{c}\text { DESCRIPTION OF } \\
\text { PARAMETER }\end{array}$} & MANAGER & SUPERVISOR & OPERATOR \\
\hline 1 & $\begin{array}{l}\text { Company uses } \\
\text { contractual worker }\end{array}$ & 46 & 46 & 46 \\
\hline 2 & $\begin{array}{l}\text { Contracts are present in } \\
\text { key area }\end{array}$ & 21 & 22 & 35 \\
\hline 3 & $\begin{array}{l}\text { Contractual workers } \\
\text { changes not frequent }\end{array}$ & 22 & 30 & 38 \\
\hline 4 & $\begin{array}{l}\text { Company has training } \\
\text { programs for contractors }\end{array}$ & 20 & 8 & 4 \\
\hline 5 & $\begin{array}{l}\text { Quality suffers due to } \\
\text { contractual workers }\end{array}$ & 12 & 32 & 38 \\
\hline 6 & $\begin{array}{l}\text { Training is imparted to } \\
\text { contractual workforce }\end{array}$ & 20 & 8 & 4 \\
\hline 7 & $\begin{array}{l}\text { Contractual workers acts } \\
\text { as operators also }\end{array}$ & 22 & 12 & 22 \\
\hline 8 & $\begin{array}{l}\text { Contractual workers are } \\
\text { more productive }\end{array}$ & 32 & 36 & 4 \\
\hline 9 & $\begin{array}{l}\text { Contractual worker need } \\
\text { to have helpers job }\end{array}$ & 22 & 28 & 42 \\
\hline & Average (Percent) & 55 & 50 & 50 \\
\hline & OVERALL PERCENT & & 52 & \\
\hline
\end{tabular}

Table 5: Affirmative response on contractual workers in key area.

\begin{tabular}{|c|c|c|c|c|c|}
\hline S.No & $\begin{array}{l}\text { OVERALL } \\
\text { ASSESSMENT }\end{array}$ & MANAGER & SUPERVISOR & OPERATOR & RANGE \\
\hline 1 & $\begin{array}{l}\text { Understanding } \\
\text { and implementing } \\
\text { productivity }\end{array}$ & 26 & 20 & 03 & 23 \\
\hline 2 & $\begin{array}{l}\text { Implementing } \\
\text { QMS enhances } \\
\text { productivity }\end{array}$ & 23 & 18 & 13 & 10 \\
\hline 3 & $\begin{array}{l}\text { Management is } \\
\text { supportive on } \\
\text { productivity }\end{array}$ & 23 & 17 & 13 & 10 \\
\hline 4 & $\begin{array}{l}\text { Contractual } \\
\text { worker and } \\
\text { Productivity }\end{array}$ & 55 & 26 & 20 & 12 \\
\hline $\begin{array}{l}\text { Average ( } \\
\text { Percent) }\end{array}$ & $\begin{array}{l}\text { OVERALL } \\
\text { AVERAGE }\end{array}$ & 25 & 50 & 14 \\
\hline
\end{tabular}

hardly practice productivity (overall sixteen percent). Thus, null hypotheses $\mathrm{H} 01$ and $\mathrm{H} 03$ do not hold true.

Study also investigated the usage of adopting productivity enhancement techniques which was found to an alarming level of just eighteen percent. This difference between managers and supervisors was five percent while compared to worker it shouted up by cent percent. Overall response of eighteen percent only made hypothesis, H04, "Neither management nor workforce opt requisite drives for becoming productive" being a part of dust bin.

Surprisingly, the response on using contractual worker has found productive. Such workers do contribute in making the system more productive, may be they work at faster rate for getting promotion to next level. Thus, null hypothesis, H05, "Productivity suffers due to deployment of contractual work culture in key areas" does not hold good and usage of casual worker adds fuel to the productivity. The support services of such workers have been appreciated.

Overall impact of all parameters revealed that twenty five percent employees do understand and work to make the system productive which is very less. Apart from this, there exists a big gap in difference of opinion among employees by fourteen percent. Manager's leads in this thought process followed by supervisors and workers are far behind in journey on this constructive path.

\section{Conclusion}

From above analysis, interpretation and discussion; following conclusion has been drawn in the form of bullet point mentioned as under:

- Indian SMEs are crazier about quantity game and hardly practice being productive. This is one of the pivotal factor eroding the organizational growth and wealth as well.

- As top managements of such organizations are directly involved in operational activities, they pay less attention in making the system productive. Modern practices of enhancing productivity are not pushed in the manufacturing system and are victim of vicious circle where production remains a buzz word always.

- Though, most of the companies have opted one or the other QMS as it is a mandatory requirement to be a supplier to auto OEMs. The evidence of its effective deployment has been missing in majority of cases, resulting companies are producing the goods on a cost which varies on daily basis.

- For reducing manpower cost, companies are deploying contractual assignments in manufacturing. In this context, companies are successful in reducing the wage-bill.

- There is a big gap in thought process among senior employees (managers), front line staff (supervisors) and process owners (supervisors) as far as productivity is concerned.

- Various equipment's and machineries are not standardized for output. There is a big gap in outputs on periodic basis. Also concept of linearity in production remains overlooked.

\section{Suggestions}

Based on above findings, we propose some suggestions which can help the SMEs in automobile industry in not becoming a part of lunch but certainly a part of getting lunch.

- The management of companies needs to deploy a culture where outputs are based on productivity, lean manufacturing and kaizens.

- The senior management should narrow down the gaps in mindset of managers, supervisor and operators by creating efficiently motivated teams.

- Accreditation to QMS should not be a show window rather it should be meant for the very purpose by implementing it all over the operations of the company.

- Aggressive training needs to be imparted to contractual workmen for making them more productive and linearity in production must be measured for controlling cost of production.

- Gauge productivity on day-to-day basis and shun using word production and opt practicing productivity throughout the organization

\section{Limitation and Futuristic Scope of Study}

Nothing is perfect in this world, thus, everything has its own limitations. This study also has few limitations describe as under:

- As the study is self-sponsored, due to limited resources, the 
Citation: Sharma S, Vashisth K, Sharma T (2014) Productivity or Production: Appraising Growth Solution for Indian SMEs. Int J Econ Manag Sci 3: 185. doi: 10.4172/2162-6359.1000185

Page 5 of 5

geographical boundary of this study comprises of automobile SMEs in NCR-Delhi.

- As the co-author are employed and keeping time constraint in mind sample size of odd forty five SMEs has been selected which does not represent whole India.

- Selected managers, supervisor and operators were interviewed; a bigger sample size could have made the study more exhaustive.

- Keeping in mind the confidentiality of study, certain key parameter involving financial statements have not been included in the presentation of this research

As it not an exhaustive study covering all aspects of productivity, it opens up new area of research in Indian automobile industry and few of those are enlisted below:

- The study can be further broadened by considering auto OEMs and Tier-1 companies.

- A sample size of all India will make the study more exhaustive.

- Other aspects of productivity based on lean-manufacturing, six-sigma, kaizens, waste-elimination, usage of information and communication tools etc. can prove to be more value additives.

- As there is a big gap among various hierarchies of organization in reacting to the issue, generates new field proposing bridging this gap.

\section{Acknowledgement}

It gives us a great pleasure to thank for a great help extended by managers, supervisors and operators of the companies in sample size of this study. We are also thankful for the valuable time spared by all of respondents without which we could not have arrived at this stage. At last not least, we thank the management for their permission and co-operation.

\section{References}

1. Niringiye A, Eliab L, Joseph S (2010) Human Capital and Labor Productivity in East African Manufacturing Firms. Current Research Journal of Economic Theory 2: 48-54.

2. Pilar R (1991) Wage Differentials and Efficiency Wage Models: Evidence from the Chilean Economy. University of Notre Dame, Kellog Institute Discussion Working Paper No. 153.

3. Theodore P, Voulgaris F (2005) Labor Productivity Growth in Greek Manufacturing Firms. Operational Research 5: 459-472.

4. OECD (1998a) Technology, Productivity and Job Creation, OECD, Paris.

5. OECD (2000) A New Economy? The Changing Role of Innovation and Information Technology in Growth, OECD, Paris.

6. Hsieh, Chang-Tai, Klenow PJ (2009) Misallocation and Manufacturing TFP in China and India. Quarterly Journal of Economics 124: 1403-1448.

7. Chad S (2004b) Product Substitutability and Productivity Dispersion. Review of Economics and Statistics 86: 534-550

8. Van Biesebroeck, Johannes (2003) Productivity Dynamics with Technology Choice: An Application to Automobile Assembly. Review of Economic Studies 70: 167-198.

9. Van Biesebroeck, Johannes (2005) Exporting Raises Productivity in SubSaharan African Manufacturing Firms. Journal of International Economics 67 373-391.

10. Bloom, Nicholas, John Van Reenen (2007) Measuring and Explaining Management Practices across Firms and Countries. Quarterly Journal of Economics 122: 1351-1408.

11. Restak, Richard (2001) Mozart's Brain and the Fighter Pilot: Unleashing Your Brain's Potential (New York: Harmony).

12. Lorraine $D$, Reed $H$, Reenen JV (2000) Who gains when workers train? The Institute of Fiscal Studies WP 00/04, UK)

13. Caselli F, Coleman WJ II (2002) The World Technology Frontier, Working Paper. 